\title{
Bioaccessibility and changes on cylindrospermopsin concentration in edible mussels with storage and processing time
}

\author{
Marisa Freitas a, b, c, Joana Azevedo a, António Paulo Carvalho a, b , Vera M. Mendes ${ }^{\mathrm{d}}$, \\ Bruno Manadas ${ }^{\mathrm{d}}$, Alexandre Campos ${ }^{\mathrm{a}}$, Vitor Vasconcelos ${ }^{\mathrm{a}, \mathrm{b}, *}$ \\ a CIIMAR/CIMAR - Interdisciplinary Centre of Marine and Environmental Research, University of Porto, Rua dos Bragas 289, P 4050-123 Porto, Portugal \\ ${ }^{\mathrm{b}}$ Faculty of Sciences, Porto University, Rua do Campo Alegre, 4169-007 Porto, Portugal \\ ${ }^{\mathrm{c}}$ Department of Environmental Health, Escola Superior de Tecnologia da Saúde do Porto, Polytechnic Institute of Porto, CISA/Research Center in \\ Environment and Health, Rua de Valente Perfeito, 322, 4400-330 Gaia, Portugal \\ ${ }^{\mathrm{d}}$ Center for Neuroscience and Cell Biology, University of Coimbra, Portugal \\ * Corresponding author. Faculty of Sciences, Porto University, Rua do Campo Alegre, 4169-007 Porto, Portugal. \\ E-mail address: vmvascon@fc.up.pt (V. Vasconcelos).
}

\section{A B S T R A C T}

The alkaloid cylindrospermopsin has been recognized of increased concern due to the global expansion of its main producer, Cylindrospermopsis raciborskii. Previous studies have shown that bivalves can accumulate high levels of cylindrospermopsin. Based on the potential for human health risks, a provisional tolerable daily intake of $0.03 \mu \mathrm{g} / \mathrm{kg}$-body weight has been recommended. However, the human exposure assessment has been based on the cylindrospermopsin concentration in raw food items. Thus, this study aimed to assess the changes on cylindrospermopsin concentration in edible mussels with storage and processing time as well as cylindrospermopsin bioaccessibility. Mussels, (Mytilus galloprovincialis) fed cylindrospermopsin-producing C. raciborskii, were subjected to the treatments and then analyzed by LC-MS/MS. Mussels stored frozen allowed a significantly higher recovery of cylindrospermopsin (52.5\% in $48 \mathrm{~h}$ and $57.7 \%$ in one week). The cooking treatments did not produce significant differences in cylindrospermopsin concentration in the mussel matrices (flesh), however, cylindrospermopsin was found in the cooking water, suggesting that heat processing can be used to reduce the availability of cylindrospermopsin. The in vitro digestion considerably decreased the cylindrospermopsin availability in uncooked and steamed mussels, highlighting the importance in integrating the bioaccessibility of cylindrospermopsinin in the human health risk assessment.

Keywords: Bioaccessibility Cylindrospermopsin Food storage Food processing In vitro digestion Mytilus galloprovincialis

Abbreviations: ACN, acetonitrile;

CYN, cylindrospermopsin;

CYP450, cyto-chrome P450;

FA, formic acid;

FAO, Food and Agriculture Organization of the United Nations;

GSH, glutathione;

HACCP, Hazard Analysis Critical Control Points;

LC-MS/MS, liquid chromatography coupled to tandem mass spectrometry;

LOQ limit of quantification; MRM, multiple reaction monitoring;

$\mathrm{SD}$, standard deviation;

TDI, tolerable daily intake; ww, wet weight.

\section{Introduction}

The occurrence and progressive proliferation of harmful cyanobacteria in freshwater, estuarine and marine ecosystems have been recognized as a potential consequence of eutrophication and climate change (O'Neil, Davis, Burford, \& Gobler, 2012). During last decades, the expansion of Cylindrospermopsis raciborskii (a planktonic freshwater cyanobacterium) from its tropical origin to temperate waterbodies has been reported (Poniedziałek, Rzymski, \& Kokociński, 2012). The cyanotoxin cylindrospermopsin (CYN), an alkaloid consisting of a hydroxymethyluracil moiety linked to a tricyclic guanidine (Ohtani, Moore, \& Runnegar, 1992) (Fig. 1), was firstly isolated from a culture of $C$. raciborskii (Ohtani et al., 1992). Since then, several CYN-producing cyanobacteria have been identified, as follows: Umezakia natans (Terao et al., 1994), Aphanizomenon ovalisporum (Banker et al., 1997), Raphidiopsis curvata (Li et al., 2001), Lyngbya wollei (Seifert, Mcgregor, Eaglesham, Wickramasinghe, \& Shaw, 2007), Anabaena bergii, Aphanizomenon flos-aquae (Preussel, Stüken, Wiedner, Chorus, \& Fastner, 2006), and Anabaena lapponica (Spoof et al., 2006). Structural variants of CYN, 7-epi-CYN and deoxy-CYN (Banker, Teltsch, Sukenik, \& Carmeli, 2000; Norris et al., 1999; Seifert et al., 2007) (Fig. 1), have also been identified. Although the molecular mechanism of CYN toxicity is not yet established, it is known that it inhibits the 


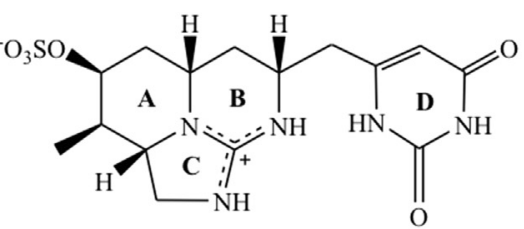

(1)<smiles></smiles>

(2)<smiles></smiles>

(3)

Fig. 1. The molecular structure of cylindrospermopsin (1) and its analogs, 7-deoxy-cylindrospermopsin (2) and 7-epicylindrospermopsin (3).

eukaryotic protein synthesis (Froscio, Humpage, Wickramasinghe, Shaw, \& Falconer, 2008; Runnegar et al., 2002) as well as glutathione (GSH) synthesis (Runnegar, Kong, Zhong, \& Lu, 1995). Furthermore, the metabolic activation of CYN by cytochrome P450 (CYP450) seems to contribute to its toxicity (Froscio, Humpage, Burcham, \& Falconer, 2003; Runnegar et al., 1995), and probably due to the high CYP450 activity in the hepatocytes, the liver seems to be the main target organ of sub-chronic oral exposure (Froscio et al., 2003; Runnegar et al., 1995). Nevertheless, although to a lesser extent, toxic effects of CYN have also been reported in kidneys, thymus, spleen, lungs, intestine and heart (Falconer et al., 1999; Froscio et al., 2003; Runnegar et al., 1995; Terao et al., 1994). Studies in mouse have shown that the overall toxic effects of CYN are delayed and progressive $\left(\mathrm{LD}_{50}\right.$ of $2100 \mu \mathrm{g} / \mathrm{kg}$ at $24 \mathrm{~h}$ and $200 \mu \mathrm{g} / \mathrm{kg}$ at 5-6 days, intra-peritoneal administration (Ohtani et al. 1992)), and they are exerted by the following mechanisms: (1) acute toxicity produced by CYP450 generated metabolites of CYN (Froscio, Humpage, Burcham, \& Falconer, 2001; Runnegar et al., 1995) and (2) a slower toxicity generated by the inhibition of protein synthesis, non-dependent of CYN metabolism (Froscio et al., 2001, 2003). The bioactivation of CYN by CYP450 seems to be responsible for the induction of genotoxic effects (Falconer \& Humpage, 2006), since CYP450 inhibitors appear to prevent DNA damage in in vitro assays (Humpage, Fontaine, Froscio, Burcham, \& Falconer, 2005; Runnegar et al., 1995). A preliminary study suggests that tumors are generated in mice by oral exposure to CYN (Falconer \& Humpage, 2001), however, it remains to be elucidated whether the genotoxic effects might increase the risk of carcinogenicity in vivo. Although the lack of consistent epidemiological data, consumption of contaminated water and food seem to be the major sources of chronic human exposure to CYN. The first human intoxication associated to CYN was in Palm Island (Queensland, Australia in 1979), where 149 people supplied with drinking water from a reservoir with CYN-producing $C$. raciborskii suffered a hepatoenteritis-like illness (Griffiths \& Saker, 2003). Since then, public health concerns because of CYN exposure have increased, and the risks associated to this toxin are still under investigation. CYN is highly water soluble due to its zwitterionic character, and contrary to the majority of cyanotoxins, as much as $90 \%$ of total CYN is outside of the cells, dissolved in the surrounding water (Chiswell et al., 1999; Rücker et al., 2007). Furthermore, CYN can persist in the water, since its photodegradation seems to be very low under natural conditions (Wörmer, Huerta-Fontela, Cirés, Carrasco, \& Quesada, 2010). Thus, the high levels and the persistence of CYN in water can potentiate its accumulation in a wide range of aquatic organisms. Indeed, previous studies have shown that aquatic organisms, especially bivalves, can accumulate high levels of CYN without lethal effect (Gutiérrez-Praena, Jos, Pichardo, Moreno, \& Cameán, 2013; Ibelings \& Chorus, 2007; Kinnear, 2010; Saker, Metcalf, Codd, \& Vasconcelos, 2004). Based on the potential for human health risks a provisional tolerable daily intake (TDI) of $0.03 \mu \mathrm{g} / \mathrm{kg}$ of body weight has been proposed by Humpage and Falconer (2003). The human exposure assessment due to the consumption of CYN-contaminated food has been based on the direct comparison between CYN concentration in raw edible organisms and TDI (Ibelings \& Chorus, 2007). However, edible organisms are usually stored and processed before consumption and these practices may change the concentration of CYN available in food. Recent studies with microcystin-LR, the most studied cyanotoxin, have shown that its recovery from food matrices is changed after applying common food storage and cooking practices, as well as proteolytic digestion (Freitas, Azevedo, Carvalho, Campos, \& Vasconcelos, 2014; Guzmán-Guillén, Prieto, Moreno, Soria, \& Cameán, 2011; Morais, Augusto, Carvalho, Vale, \& Vasconcelos, 2008; Zhang, Xie, \& Chen, 2010). According to our knowledge and as it was recently reviewed by Gutiérrez-Praena et al. (2013) there are no studies regarding to the influence of different food storage and cooking procedures on the CYN concentration in edible organisms. Furthermore, from the health risk point of view, the oral bioavailability of CYN is an important parameter to consider, once it can vary from the CYN contained in food matrices. The bioavailability of a contaminant depends on its (1) bioaccessibility, (2) transport across the intestinal epithelium into the portal vein and (3) metabolism, mainly in the liver (Versantvoort, Oomen, Van de Kamp, Rompelberg, \& Sips, 2005). The bioaccessibility corresponds to the fraction of a contaminant that is released from food matrix by digestive juices and can be seen as an appropriate indicator of the maximal oral bioavailability. Nowadays, several in vitro digestion models can be used to determine bioaccessibility, by simulating in a simplified manner the digestion processes in mouth, stomach and small intestine (Guerra et al., 2012).

CYN is highly water-soluble and stable to extreme temperatures and $\mathrm{pH}$ (Chiswell et al., 1999), thus the knowledge of the influence of common food storage and processing practices as well as human digestion is required to achieve a more accurate human health risk assessment. Therefore, the aim of this study was to assess the changes on CYN concentration in edible mussels with storage and processing time as well as to assess the bioaccessibility of CYN in raw and processed (steamed) edible mussels. 


\section{Material and methods}

\subsection{Reagents and chemicals}

The mammalian enzymes $\alpha$-amylase (A-3176), pepsin (P7000), trypsin (T0303), chymotrypsin (C4129), pancreatin (P1750) and bile salts (B-8756) were purchased from Sigma-Aldrich (St. Louis, MO, USA). Potassium chloride ( $\mathrm{KCl}, 99.5-100 \%)$, sodium chloride $(\mathrm{NaCl}$, $\geq 98 \%$ ), sodium phosphate monobasic $\left(\mathrm{NaH}_{2} \mathrm{PO}_{4}, 98-102 \%\right)$, sodium hydrogen carbonate $\left(\mathrm{NaHCO}_{3}, 99 \%\right)$, ammonium chloride $\left(\mathrm{NH}_{4} \mathrm{Cl}\right.$, A-0171), calcium chloride dihydrate $\left(\mathrm{CaCl}_{2} \cdot 2 \mathrm{H}_{2} \mathrm{O},>99 \%\right)$, hydrochloric acid $(\mathrm{HCl}, 37 \%, \mathrm{~g} / \mathrm{g})$, glucosamine hydrochloride (>99\%), bovine serum albumin (BSA, $98 \%)$, magnesium chloride $\left(\mathrm{MgCl}_{2}\right.$, $99 \%$ ), sodium sulfate $\left(\mathrm{Na}_{2} \mathrm{SO}_{4}, \geq 99 \%\right)$, potassium phosphate monobasic $\left(\mathrm{KH}_{2} \mathrm{PO}_{4}, \geq 99 \%\right)$, glucuronic acid (97.5-102.5\%), glucose (99.5\%), uric acid (99\%) and urea were analytical grade and were also purchased from the Sigma-Aldrich (St. Louis, MO, USA). Analytical grade potassium thiocyanate (KSCN, 99\%) was purchased from Merck (Germany). All solutions were prepared with ultrapure water supplied by a Millipore water purification system $(0.0054 \mu \mathrm{S} /$ $\mathrm{cm}$ ) (MilliQ water). The acetonitrile (ACN) and water used for CYN extraction were analytical grade and all solvents used in liquid chromatography coupled to tandem mass spectrometry (LC-MS/ MS) analysis were high-purity LC-MS grade (HiPerSolv CHROMANORM $^{\circledR}$ for LC-MS, VWR). Reagents used in the Z8 medium were analytical grade. Analytical grade purity CYN was used as the reference standard (Lot\# 20050531, CAS No.: 143545-90-8, National Research Council, Canada).

\subsection{Biological material - cyanobacterial culture and mussels}

The exposure experiment was carried out with CYN-producing cells of C. raciborskii (LEGE 97047). Cyanobacteria were cultured to the death phase in Z8 medium (Kotai, 1972) (6 L flask) under fluorescent light (light/dark cycle of 14/10 h) and a temperature of $25 \pm 1{ }^{\circ} \mathrm{C}$. Live mussels, Mytilus galloprovincialis (Lamark, 1819), with a mean shell length of $6.50 \pm 0.56 \mathrm{~cm}(\mathrm{n}=90)$ were purchased in a Portuguese local market as for human consumption. The mussels were acclimated for two weeks prior to the experiment in $20 \mathrm{~L}$ aquaria with seawater. During this period, the mussels were fed twice a week with Chlorella vulgaris $\left(10^{5}\right.$ cells $\left./ \mathrm{mL}\right)$. The water was renewed weekly.

\subsection{Exposure and experiment}

\subsubsection{Mussels intoxication}

The presence of CYN as well as the occurrence and growth of C. raciborskii in marine ecosystems have not yet been documented. However, recently, Vareli et al. (2012) found microcystins (freshwater cyanotoxins) in concentrations ranging from $45 \pm 2$ to $141.5 \pm 13.5 \mathrm{ng} / \mathrm{g}$ in specimens of M. galloprovincialis collected from Mediterranean Sea, NW Greece. This raised attention for the potential negative impacts of freshwater cyanotoxins in marine aquaculture in Mediterranean estuaries. Therefore, in this study it was attempted to simulate a contamination of estuarine or seashore ecosystem with senescent toxic cyanobacterial blooms. Mussels were intoxicated with cyanobacterial crude extract (cells and culture medium) for four days in static conditions $(\approx 10-15 \mu \mathrm{g} / \mathrm{L}$ of CYN per day). During the exposure experiment, the physical and chemical conditions of the seawater were as follows: temperature $17.5 \pm 1.3^{\circ} \mathrm{C}$, salinity $32.84 \pm 0.58 \%$ and $\mathrm{pH} 8.25 \pm 0.23$.

\subsubsection{Simulation of food storage and processing practices}

The common food storage and processing practices applied in this study were performed according to Freitas et al. (2014), with some modifications. Briefly, at the end of four days of exposure, mussels were rinsed with tap water and weighed, and sets of six animals for each treatment (two mussels per replicate, three biological replicates, $n=6$ ) were submitted to the common food storage (refrigeration and freezing) and processing (boiling, steaming and microwaving) procedures for different periods of time as shown in Table 1. After exposure to C. raciborskii, one group of mussels was depurated for 8 days (the seawater was renewed every two days). At the end of the depuration period, mussels were analyzed raw and after steaming $10 \mathrm{~min}$. The experimental control group was not stored or processed, being immediately extracted for toxin quantification. The boiling time began after the water reached $100{ }^{\circ} \mathrm{C}$. The ratio of water: mussels in the processing treatments was $10 \mathrm{~mL}$ of MilliQ water: two mussels. The remaining water in which mussels were cooked was also analyzed and its evaporation was not prevented throughout the experiment, in order to simulate the usual household cooking procedures.

\subsubsection{In vitro digestion}

The in vitro model used to simulate the human digestion was adapted from Hur, Decker, and McClements (2009), Maulvault et al. (2011) and Versantvoort et al. (2005), with some modifications. Briefly, after exposure, mussels were rinsed with tap water and weighed. Mussels uncooked and cooked (steamed, $10 \mathrm{~min}$ as in 2.3.2) were removed from shells and homogenized with a blender for 1-2 min. Approximately $2 \mathrm{~g}(\mathrm{ww})$ of the homogenate from both treatments were transferred to a $50 \mathrm{~mL}$ sterile centrifuge tubes and then submitted to a chemical digestion as is schematized in Fig. 2. The digestive procedure was made in triplicate and samples were sequentially incubated in a shaking water bath (GFL 1083, GFL, Germany) at $37^{\circ} \mathrm{C}$ for: (1) 5 min with salivary juice ( $6 \mathrm{~mL}$; 12 tubes), followed by (2) $1 \mathrm{~h}$ with gastric juice ( $12 \mathrm{~mL} ; 9$ tubes) and (3) $2 \mathrm{~h}$ with duodenal juices, which were individually tested, simulating digestion in small intestine by the proteolytic enzymes trypsin and chymotrypsin (12 $\mathrm{mL}$ and $2 \mathrm{~mL} \mathrm{HCO}_{3}(1 \mathrm{M}) ; 3$ tubes) or by the whole pancreatic juice, containing pancreatic proteolytic enzymes as well as pancreatic amylase and lipase $(12 \mathrm{~mL}, 6 \mathrm{~mL}$ bile juice and $2 \mathrm{~mL}$ $\mathrm{HCO}_{3}(1 \mathrm{M}) ; 3$ tubes). The composition of digestive juices is shown in Table 2. At the end of each digestive stage (mouth, stomach and small intestine) samples were stored at $4{ }^{\circ} \mathrm{C}$ in order to stop the enzymatic reactions. Soluble and non-soluble fractions from each digestive phase were obtained by centrifugation (Thermo Scientific - Legend ${ }^{\mathrm{TM}} \mathrm{T} / \mathrm{RT}$ QUIKset ${ }^{\mathrm{TM}}$, Germany) (20 min, $4{ }^{\circ} \mathrm{C}, 4495 \mathrm{~g}$ ). Groups of intoxicated mussels, either raw or cooked, without chemical digestion, were used as experimental controls. Purified CYN in solution $(100 \mathrm{ng} / \mathrm{mL})$ was also subjected to the same enzymatic treatments.

\subsection{CYN determination}

\subsubsection{CYN extraction and clean-up}

In order to avoid any interference in the final concentration of the toxin through sample freezing/thawing, CYN from all samples (except soluble fractions from digestion experiments, which were lyophilized) was immediately extracted after each treatment.

Mussels of the Section 2.3.2 and solid fractions of the Section 2.3.3 were weighed, removed from shells and homogenized with a blender for $1-2 \mathrm{~min}$. Approximately $1 \mathrm{~g}$ (ww) of the homogenate was transferred to a $50 \mathrm{~mL}$ sterile centrifuge tubes and CYN was extracted twice in $5 \mathrm{~mL}$ of $90 \%$ ACN by ultrasonication (750 Watt, $20 \mathrm{KHz}$ ) (BioBlock Scientific, Vibracell 75041) in an ice bath for $1 \mathrm{~min}$ (pulse $1 \mathrm{~s}$, amplitude 40) and then centrifuged (Eppendorf, 5810R) ( $5 \mathrm{~min}, 4^{\circ} \mathrm{C}, 3200 \mathrm{~g}$ ). For the clean-up of the extracts, both supernatants were pooled in $0.5 \mathrm{~g}$ of $\mathrm{C} 18$ powder (Bakerbond Octadecyl $40 \mu \mathrm{m}$, Prep LC Packing, J.T. Backer) and homogenized for 
Table 1

Food storage and processing practices applied in the experiment.

\begin{tabular}{|c|c|c|c|c|c|c|}
\hline \multirow[t]{2}{*}{ Conditions } & \multicolumn{3}{|c|}{ Storage process } & \multicolumn{3}{|l|}{ Cooking process } \\
\hline & $25^{\circ} \mathrm{C}$ & $4^{\circ} \mathrm{C}$ & $-20^{\circ} \mathrm{C}$ & Microwaving (550 W) & Boiling $\left(100^{\circ} \mathrm{C}\right)$ & Steaming \\
\hline Period of time & $\begin{array}{l}0 \mathrm{~h} \\
24 \mathrm{~h}\end{array}$ & $\begin{array}{l}24 \mathrm{~h} \\
48 \mathrm{~h}\end{array}$ & $\begin{array}{l}48 \mathrm{~h} \\
1 \text { week } \\
1 \text { month }\end{array}$ & $\begin{array}{l}0.5 \mathrm{~min} \\
1 \mathrm{~min}\end{array}$ & $\begin{array}{l}5 \mathrm{~min} \\
10 \mathrm{~min} \\
15 \mathrm{~min}\end{array}$ & $\begin{array}{l}10 \mathrm{~min} \\
15 \mathrm{~min}\end{array}$ \\
\hline
\end{tabular}

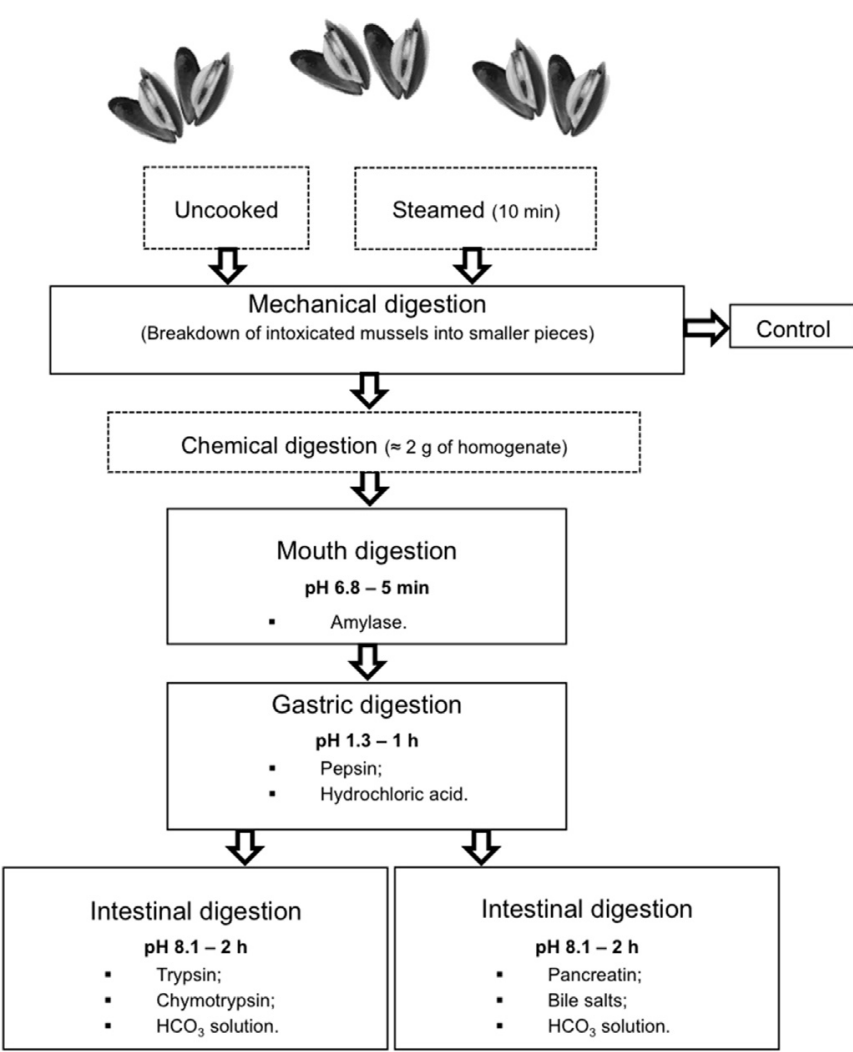

Fig. 2. Schematic representation of the in vitro digestion model used in the experiment.
$1 \mathrm{~min}$ at $25{ }^{\circ} \mathrm{C}, 1300 \mathrm{rpm}$ (thermomixer comfort Eppendorf MTP). The supernatant $(9 \mathrm{~mL})$ was recovered by centrifugation $(1 \mathrm{~min}$, $20{ }^{\circ} \mathrm{C}, 2000 \mathrm{~g}$ ) and $900 \mu \mathrm{L}$ were then evaporated to dryness in a SpeedVac (Eppendorf). The residue was re-suspended in $200 \mu \mathrm{L}$ $0.1 \%$ formic acid (FA) in water $(\mathrm{v} / \mathrm{v})$. Samples were stored at $-80^{\circ} \mathrm{C}$ until further LC-MS/MS analysis.

\subsubsection{LC-MS/MS analysis}

The quantification of CYN was carried out by linear regression of six-point calibration curves of mussel matrix spiked (in triplicate) with a standard solution of CYN $(50 ; 100 ; 200 ; 400 ; 800$ and $1600 \mathrm{ng} / \mathrm{g})$. The lowest standard of the calibration curve $(50 \mathrm{ng} / \mathrm{g}$ ) was the limit of quantification (LOQ). The potential interference of matrix components in the LC-MS/MS chromatograms was also assessed (in three independent pools in triplicate) and the method revealed to be selective for CYN quantification (data not shown).

Samples were analyzed on an Ultimate ${ }^{\mathrm{TM}} 3000$ LC system (LC Packings, Dionex) coupled to an ESI Turbo V ion source and an hybrid triple quadrupole/linear ion-trap 4000 QTrap mass spectrometer operated by Analyst 1.6.1 (AB Sciex). The chromatographic separation was performed in a $3 \mu \mathrm{m}$ Luna $\mathrm{NH}_{2}$ column $(150 \times 2.0 \mathrm{~mm}, 100 \AA$, Phenomenex $)$ with a $4 \times 2.0 \mathrm{~mm} \mathrm{NH}$ guardcolumn (Phenomenex). The flow rate was set to $150 \mu \mathrm{L} / \mathrm{min}$ and mobile phase A and B were 0.1\% FA in water and 0.1\% FA in ACN, respectively. The LC program started with a linear gradient from $50 \%$ to $5 \%$ of B $(0-0.5 \mathrm{~min})$ and it was maintained at $5 \%$ of B for 6 min. After each sample analysis, a 6 min run was performed in isocratic mode with $50 \%$ of B for column equilibration. The ionization source was operated in the positive mode set to an ion spray voltage of $5500 \mathrm{~V}, 30$ psi for nebulizer gas 1 (GS1), 20 psi for the nebulizer gas 2 (GS2), 30 psi for the curtain gas (CUR) and the

Table 2

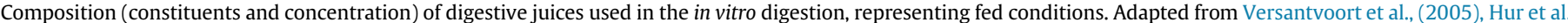
(2009) and Maulvault et al. (2011).

\begin{tabular}{|c|c|c|c|c|c|}
\hline \multirow[t]{2}{*}{ Components } & \multicolumn{5}{|c|}{ Digestive juices (g/L) } \\
\hline & Saliva & Gastric & Duodenal (pancreatin) & Duodenal (proteases) & Bile \\
\hline \multirow[t]{9}{*}{ Inorganic solution } & $0.9 \mathrm{~g} \mathrm{KCl}$ & $0.82 \mathrm{~g} \mathrm{KCl}$ & $0.56 \mathrm{~g} \mathrm{KCl}$ & $0.56 \mathrm{~g} \mathrm{KCl}$ & $0.38 \mathrm{~g} \mathrm{KCl}$ \\
\hline & $0.3 \mathrm{~g} \mathrm{NaCl}$ & $2.75 \mathrm{~g} \mathrm{NaCl}$ & $7 \mathrm{~g} \mathrm{NaCl}$ & $7 \mathrm{~g} \mathrm{NaCl}$ & $5.26 \mathrm{~g} \mathrm{NaCl}$ \\
\hline & $1.7 \mathrm{~g} \mathrm{NaHCO}_{3}$ & & $3.39 \mathrm{~g} \mathrm{NaHCO}_{3}$ & $3.39 \mathrm{~g} \mathrm{NaHCO}_{3}$ & $5.79 \mathrm{~g} \mathrm{NaHCO}_{3}$ \\
\hline & & & $0.08 \mathrm{~g} \mathrm{KH}_{2} \mathrm{PO}_{4}$ & $0.08 \mathrm{~g} \mathrm{KH}_{2} \mathrm{PO}_{4}$ & \\
\hline & $0.89 \mathrm{~g} \mathrm{NaH}_{2} \mathrm{PO}_{4}$ & $0.27 \mathrm{~g} \mathrm{NaH}_{2} \mathrm{PO}_{4}$ & & & \\
\hline & $0.2 \mathrm{~g} \mathrm{KSCN}$ & $0.31 \mathrm{~g} \mathrm{NH}_{4} \mathrm{Cl}$ & $0.05 \mathrm{~g} \mathrm{MgCl}_{2}$ & $0.05 \mathrm{~g} \mathrm{MgCl}_{2}$ & \\
\hline & $0.58 \mathrm{~g} \mathrm{Na}_{2} \mathrm{SO}_{4}$ & & & & \\
\hline & & $0.4 \mathrm{~g} \mathrm{CaCl}_{2} \cdot 2 \mathrm{H}_{2} \mathrm{O}$ & $0.2 \mathrm{~g} \mathrm{CaCl}_{2} \cdot 2 \mathrm{H}_{2} \mathrm{O}$ & $0.2 \mathrm{~g} \mathrm{CaCl}_{2} \cdot 2 \mathrm{H}_{2} \mathrm{O}$ & $0.22 \mathrm{~g} \mathrm{CaCl}_{2} \cdot 2 \mathrm{H}_{2} \mathrm{O}$ \\
\hline & & $6.5 \mathrm{~mL} \mathrm{HCl} 37 \% \mathrm{~g} / \mathrm{g}$ & $180 \mu \mathrm{L} \mathrm{HCl} 37 \% \mathrm{~g} / \mathrm{g}$ & $180 \mu \mathrm{L} \mathrm{HCl} 37 \% \mathrm{~g} / \mathrm{g}$ & $150 \mu \mathrm{L} \mathrm{HCl} 37 \% \mathrm{~g} / \mathrm{g}$ \\
\hline \multirow[t]{5}{*}{ Organic solution } & $0.2 \mathrm{~g}$ Urea & $0.085 \mathrm{~g}$ Urea & $1 \mathrm{~g}$ Urea & $1 \mathrm{~g}$ Urea & $0.25 \mathrm{~g}$ Urea \\
\hline & & $1 \mathrm{~g} \mathrm{BSA}$ & $1 \mathrm{~g} \mathrm{BSA}$ & $1 \mathrm{~g}$ BSA & $1.8 \mathrm{~g} \mathrm{BSA}$ \\
\hline & & $0.02 \mathrm{~g}$ Glucuronic acid & & & \\
\hline & & 0.65 g Glucose & & & \\
\hline & & $0.33 \mathrm{~g}$ Glucosamine hydrochloride & & & \\
\hline \multirow[t]{2}{*}{ Bioactive (Enzyme) } & $0.29 \mathrm{~g} \alpha$-Amylase & $2.5 \mathrm{~g}$ Pepsin & 9 g Pancreatin & 9 g Trypsin & $30 \mathrm{~g}$ Bile salts \\
\hline & $0.015 \mathrm{~g}$ Uric acid & & & 9 g Chymotrypsin & \\
\hline $\mathrm{pH}$ & $6.8 \pm 0.2$ & $1.3 \pm 0.02$ & $8.1 \pm 0.2$ & $8.1 \pm 0.2$ & $8.2 \pm 0.2$ \\
\hline
\end{tabular}


temperature was $450{ }^{\circ} \mathrm{C}$. Cylindrospermopsin was quantified by Multiple Reaction Monitoring (MRM) triple quadrupole scan mode, at unit resolution both in Q1 and Q3 and the MRM transitions were 416.4/194.3 (used for quantification), 416.4/176.1 and 416.4/336.5 (both used for compound confirmation). The MRM parameters used were $10 \mathrm{eV}$ for the entrance potential (EP), $15 \mathrm{eV}$ for the collision cell exit potential (CXP), $100 \mathrm{~V}$ for the declustering potential (DP) and the collision gas (CAD) was set to 8 psi. The dwell time was set to $100 \mathrm{~ms}$ and the collision energies were $50 \mathrm{eV}$ for transition 416.4/176.1, $60 \mathrm{eV}$ for transition 416.4/176.1 and $32 \mathrm{eV}$ for transition 416.4/336.5. Peak areas were integrated using MultiQuant software (version 2.1, AB Sciex).

\subsection{Statistical analysis}

Statistical analysis of data was performed by one-way ANOVA, after checking the homogeneity of variance with the Levene test. When necessary, data were transformed to achieve the variance homogeneity assumption. The Tukey multiple range test was used to compare means whenever differences were detected by ANOVA at the significance level of 0.05 . All analyses were run with the IBM SPSS Statistics, version 22. Four individual data groups were considered for statistical analysis, as follows: (1) CYN concentration in control group and CYN concentration after applying the storage practices; (2) CYN concentration in control group and CYN concentration after applying the cooking practices; (3) CYN concentration in control group and CYN concentration in mussels depurated (analyzed raw or after cooking) and (4) CYN in solution before and after in vitro digestion. Significant differences were also tested between different periods of time in the groups belonging to storage and processing treatments. Results are expressed in $\mathrm{ng} / \mathrm{g}$ (ww) as the mean \pm standard deviation (SD) for three replicates for each treatment.

\section{Results and discussion}

The estimation of human exposure to CYN by food consumption is an essential element for quantifying the risk, thus data on the concentration of CYN in edible organisms are required. In this study, marine mussels (M. galloprovincialis) were able to accumulate CYN $(28.1 \pm 4.9$ to $41.6 \pm 5.7 \mathrm{ng} / \mathrm{g}$; whole organism $)$ when exposed to ecologically relevant concentrations $(\approx 10-15 \mu \mathrm{g} / \mathrm{L})$ for four days, showing neither mortality nor apparent detrimental effect on their organoleptic characteristics. As above-mentioned (Section 2.3.1), recently, Vareli et al. (2012) have found microcystins in M. galloprovincialis collected from Mediterranean Sea, supporting that this edible aquatic organism could contribute for chronic human exposure to cyanotoxins. Shellfish is an important component of human diet, thus the study of the influence of common food storage and processing practices as well as the human digestion on CYN availability in these edible organisms are of major significance, in order to provide more accurate data of human exposure to this cyanotoxin.

\subsection{Effects of storage on CYN concentration in the edible mussels}

The storage process is a critical step to provide safe and high quality shellfish for human consumption. Thus, in this study we intend to determine if different storage conditions may lead to changes on the levels of CYN in edible mussels. The concentration of CYN in mussels stored unrefrigerated $\left(25^{\circ} \mathrm{C}\right)$ for $24 \mathrm{~h}$ $(43.1 \pm 4.1 \mathrm{ng} / \mathrm{g})$ and stored refrigerated $\left(4{ }^{\circ} \mathrm{C}\right)$ for $24 \mathrm{~h}$ $(45.3 \pm 0.8 \mathrm{ng} / \mathrm{g})$ or $48 \mathrm{~h}(55.7 \pm 14.6 \mathrm{ng} / \mathrm{g})$ did not significantly differ from the control group $(41.6 \pm 5.7 \mathrm{ng} / \mathrm{g}$ ) (Table 3). The chemical stability of CYN is an important factor associated to its
Table 3

The concentration of CYN in: (1) mussel matrix submitted to different storage and processing treatments (ng/g); (2) water in which mussels were cooked (ng/mL) and (3) uncooked depurated (1 week) and steamed depurated mussel matrices (ng/g). Values are expressed as the mean $\pm \operatorname{SD}(\mathrm{n}=3)$. Different superscript letters $(\mathrm{a}$, b and c) indicate significant differences $(p<0.05)$. Conditions that share the same superscript letter are not significantly different. *The asterisk denotes the control group.

\begin{tabular}{|c|c|c|c|c|}
\hline \multirow[t]{2}{*}{ Conditions } & & \multirow[t]{2}{*}{ Time } & \multicolumn{2}{|c|}{ Concentration of CYN } \\
\hline & & & Mussels (ng/g) & Water $(\mathrm{ng} / \mathrm{mL})$ \\
\hline \multirow[t]{7}{*}{ Storage } & $25^{\circ} \mathrm{C}$ & $0 \mathrm{~h}^{*}$ & $41.6 \pm 5.7^{\mathrm{a}}$ & NA \\
\hline & & $24 \mathrm{~h}$ & $43.1 \pm 4.1^{\mathrm{a}}$ & NA \\
\hline & $4{ }^{\circ} \mathrm{C}$ & $24 \mathrm{~h}$ & $45.3 \pm 0.8^{\mathrm{a}}$ & NA \\
\hline & & $48 \mathrm{~h}$ & $55.7 \pm 14.6^{\mathrm{ab}}$ & NA \\
\hline & $-20^{\circ} \mathrm{C}$ & $48 \mathrm{~h}$ & $87.6 \pm 15.6^{b c}$ & NA \\
\hline & & 1 week & $98.2 \pm 23.6^{c}$ & NA \\
\hline & & 1 month & $60.3 \pm 13.8^{\mathrm{abc}}$ & NA \\
\hline \multirow[t]{7}{*}{ Cooking } & Boiling & $5 \mathrm{~min}$ & $48.1 \pm 10.2$ & $12.3 \pm 1.5$ \\
\hline & & $10 \mathrm{~min}$ & $56.9 \pm 8.1$ & $8.2 \pm 1.1$ \\
\hline & & $15 \mathrm{~min}$ & $60.9 \pm 14.5$ & $7.1 \pm 1.0$ \\
\hline & Steaming & $10 \mathrm{~min}$ & $50.8 \pm 0.5$ & $7.3 \pm 1.9$ \\
\hline & & $15 \mathrm{~min}$ & $42.7 \pm 10.8$ & $5.0 \pm 0.2$ \\
\hline & Microwaving & $0.5 \mathrm{~min}$ & $47.9 \pm 9.8$ & $7.5 \pm 2.0$ \\
\hline & & $1 \mathrm{~min}$ & $47.5 \pm 3.6$ & $7.2 \pm 0.6$ \\
\hline \multirow[t]{2}{*}{ Depuration } & Uncooked & $0 \mathrm{~h}$ & $45.8 \pm 6.2$ & NA \\
\hline & Steaming & $10 \mathrm{~min}$ & $32.6 \pm 7.9$ & ND \\
\hline
\end{tabular}

NA, not applicable. ND, not detected.

environmental persistence and toxicity. In aqueous media, the stability of CYN has already been demonstrated at temperatures ranging from 4 to $50{ }^{\circ} \mathrm{C}$ for up to four weeks (Chiswell et al., 1999).

In mussels stored frozen $\left(-20^{\circ} \mathrm{C}\right)$ the recovery of CYN increased, especially after $48 \mathrm{~h}(87.6 \pm 15.6 \mathrm{ng} / \mathrm{g})$ and one week $(98.2 \pm 23.6 \mathrm{ng} / \mathrm{g})$ of storage, where the concentration of CYN was significantly higher $52.5 \%$ and $57.7 \%$, respectively, $(p<0.05)$ than the control group (Table 3). Froscio et al. (2008) have shown that in reticulocyte lysates $\left[{ }^{14} \mathrm{C}\right] \mathrm{CYN}$ was partially released by incubation with an excess of unlabeled CYN, suggesting that the toxin binds reversibly. Thus, our results can be associated to a more efficient extraction of CYN from mussel tissues due to the potential cell disruption and protein denaturation caused by freezing/thawing. These results may have relevance for monitoring programs of CYN in edible organisms, in which the frozen storage of samples before its analysis is usual. Furthermore, this increase in CYN recovery from the mussel matrix, may suggest that higher levels of the toxin can be available when mussels are consumed after being frozen.

\subsection{Effects of cooking on CYN concentration in the edible mussels}

Shellfish is generally cooked prior to consumption in order to enhance its microbiological safety and flavor. However, cooking treatments can also alter the availability of chemical contaminants in food (Domingo, 2011). As recently reviewed by Gutiérrez-Praena et al. (2013) and Kinnear (2010), several studies have assessed the concentration of CYN in edible organisms; however, all analyses were performed in uncooked/raw matrices. In this study, we investigated the effects of boiling, steaming and microwaving for different periods of time on the CYN concentration in mussels. Overall, the application of these processing treatments, i.e., boiling (5, 10 and $15 \mathrm{~min}$ ); steaming (10 and $15 \mathrm{~min}$ ) and microwaving (0.5 and $1 \mathrm{~min}$ ), did not produce significant changes in the concentration of CYN in mussels in comparison to control group $(41.6 \pm 5.7 \mathrm{ng} / \mathrm{g}, p<0.05)$ (Table 3$)$, suggesting that cooking cannot remove or produce alterations in the CYN availability in mussel matrix (flesh). However, since a substantial concentration of the toxin (also not significantly different between treatments) was found in the water in which mussels were cooked (Table 3), the CYN 
quantified in the mussel matrix cannot be representative of the real amount available in these organisms. In fact, heat processing causes loss of water with soluble compounds from the mussel matrix into the intervalval fluid, which would be leaked into the cooking water due to shell opening shortly after the beginning (approximately $3 \mathrm{~min}$ ) of the treatment. Therefore, it is very likely that this fluid brought the CYN found in cooking water. In view of this, the potential human exposure to CYN due to consumption of contaminated mussels based on the amount of CYN in raw mussels will be under-evaluated. On the other hand, as the heat processing seems to enhance the CYN extraction from mussel tissues, this practice could be applied to reduce its availability in this food item, by simply rejecting the cooking water. This can be relevant for other industrial processes applied in mussels, such as canning and brine. According to the Food and Agriculture Organization of the United Nations (FAO), canning represents about $40-50 \%$ of mussel market. Normally, mussels are precooked in steam or boiling water in order to separate the edible portion from the shells, and the remaining liquor can be kept for reuse in canning or brine. The latter procedure should be absolutely avoided since the sauce is usually ingested together with mussels, which may potentially increase the human exposure to CYN. Considering the Hazard Analysis Critical Control Points (HACCP) system set by the Codex Alimentarius Commission, our results may provide new insights to identify critical control points and determine critical limits for the culinary preparations of mussels. The heat processing and the rejection of cooking water seem to be suitable procedures to, at least, reduce the availability of CYN in mussels. Besides the heat processing, we hypothesized that depuration could play a role in the reduction of CYN in mussels. Thus, the effect of depuration on the CYN concentration in raw and steamed (10 min) mussels was also considered (Table 3). However, the concentration of CYN in uncooked/ depurated and steamed/depurated mussels was not significantly reduced in comparison to control group $(p<0.05)$, suggesting that this process has no any effect on the CYN availability in mussel matrix. Saker et al. (2004) have studied the depuration pattern of CYN in the freshwater mussel Anodonta cygnea for two weeks, and found a decrease in the CYN concentration at the beginning of the depuration period (first four days), followed by a rise from the sixth to twelfth day of depuration. Depuration presupposes that shellfish expels contaminants from their gills and intestinal tract by pumping clear seawater. Once CYN is almost all dissolved in the surround medium and not inside the cells (Chiswell et al., 1999; Rücker et al., 2007), its accumulation in the intestinal tract due to the ingestion of cyanobacterial cells must have been residual, and probably, that is why the depuration was not effective in reducing CYN in mussel tissues. However, it should be noticed that CYN was not detected in the steaming water of depurated mussels, contrarily to the steaming water of non-depurated mussels, in which the concentration of CYN was of $7.3 \pm 1.9 \mathrm{ng} / \mathrm{mL}$ (Table 3 ). Although the depuration process had no effect on the CYN concentration in mussel tissues (flesh), an amount of the toxin was removed with this procedure, most likely due to the renewal of the intervalval water of mussels.

\subsection{Bioaccessibility of CYN}

The ingestion of contaminated food is an important route of chronic exposure to CYN. However, the human health risk due to the presence of CYN in food depends on its release from the food matrix by the digestive juices, i.e., its bioaccessibility. Usually, food is cooked before ingestion, which can enhance the bioaccessibility of contaminants due to the increased digestibility of food constituents (e.g., proteins because of denaturation). In this study, the calculation of CYN bioaccessibility in raw and cooked mussels was attempted using an in vitro digestion model, which mimics the composition of digestive juices along the human digestive tract (mouth, stomach and small intestine) (Hur et al., 2009; Maulvault et al., 2011; Versantvoort et al., 2005).

In general, CYN was detected after all digestion steps; however, final concentrations were below the LOQ $(50 \mathrm{ng} / \mathrm{g})$ in both liquid (bioaccessible) and solid fractions (residue resulting from each digestive phase). This was probably due to the relatively low initial concentration of CYN in mussels $(28.1-51.9 \mathrm{ng} / \mathrm{g}$, after 4 days of exposure). Freshwater organisms can be exposed for longer periods and can accumulate much higher concentrations of CYN, as in the case of the freshwater mussel Anodonta cygnea that was able to accumulate up to about 50-100 times more CYN $(2.5 \mu \mathrm{g} / \mathrm{g})$ when exposed to a $\mathrm{CYN}$-containing $C$. raciborskii extract for sixteen days (Saker et al., 2004). Nevertheless, the peak areas of the chromatograms obtained suggest that the sequential exposure of mussels to digestive juices progressively decrease the availability of CYN to levels near zero in both fractions (Figs. 3 and 4). In order to confirm the decrease in CYN content after being submitted to digestive juices and to exclude any interference of food matrix on CYN detection in the bioaccessible fraction (toxin bound to proteins or other molecules), purified CYN in solution (100 ng/mL) was submitted to the same in vitro digestion model. The results show the same trend of the intoxicated mussels, where the digestive juices sequentially reduced CYN to levels near zero (Fig. 5). The incubation of CYN with salivary juice promotes the most significant reduction on its concentration $(90 \%, p<0.05)$. Then, there was a progressive decrease in CYN availability after digestion with gastric juice (P) and intestinal proteolytic juice (PE) (98 and 99\%, respectively, $p<0.05$ ). This result supports the finding that CYN-producing C. raciborskii is at least 25 times less toxic to mice by the oral route than by the intraperitoneal route (Falconer et al., 1999). The action of the digestive juices to the alkaloid-CYN degradation is unclear. Merkel et al. (2012), using a similar in vitro digestion model, also found degradation (at a moderate extent) of some ergot alkaloids by digestive juices, which was simply attributed to the presence of the digestive enzymes and varying $\mathrm{pH}$ conditions. On the other hand, it has been recently shown that some plant alkaloids can bind to bovine $\alpha$-chymotrypsin (Zsila, Kámán, Bogányi, \& Józsvai, 2011) and fungal $\alpha$-amylase (Tintu, Dileep, Augustine, \& Sadasivan, 2012). Therefore, the possibility of the decreasing in CYN concentration measured during this experiment being due to the binding of CYN to digestive enzymes and its subsequent nondetection, cannot be discarded.

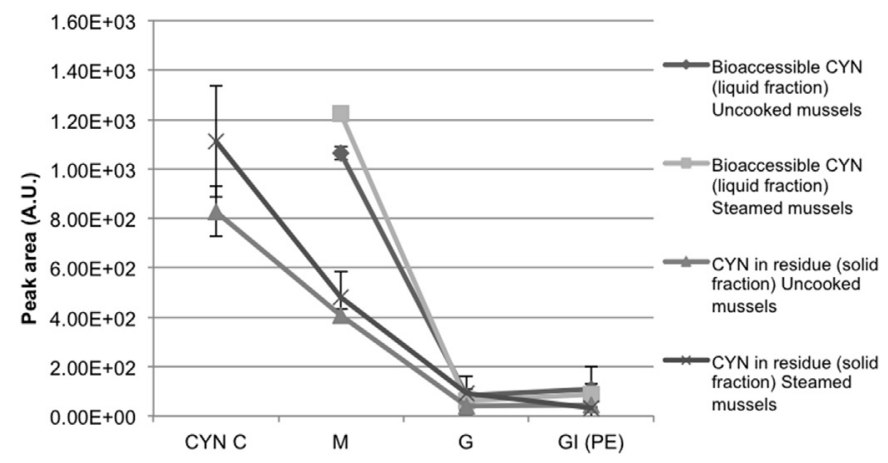

Fig. 3. Chromatographic peak area of CYN detection from uncooked and steamed mussels before (CYN C) and after digestion (for liquid and solid fractions). Letters represent each digestive step: mouth $(\mathrm{M})$, gastric $(\mathrm{G})$ and gastrointestinal (GI) with proteolytic enzymes (PE). Values are expressed as the mean $\pm S D(n=3)$. A.U., Arbitrary Units. 


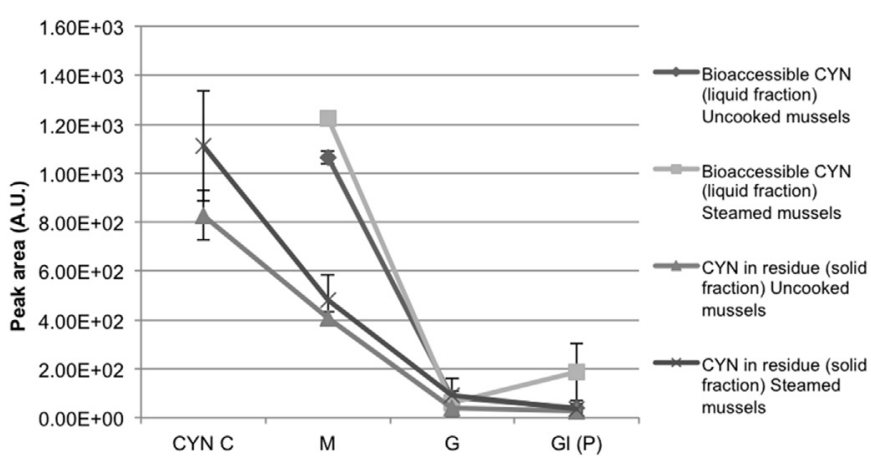

Fig. 4. Chromatographic peak area of CYN detection from uncooked and steamed mussels before (CYN C) and after digestion (for liquid and solid fractions). Letters represent each digestive step: mouth $(M)$, gastric $(G)$ and gastrointestinal (GI) with pancreatic juice $(P)$. Values are expressed as the mean $\pm S D(n=3)$. A.U., Arbitrary Units.

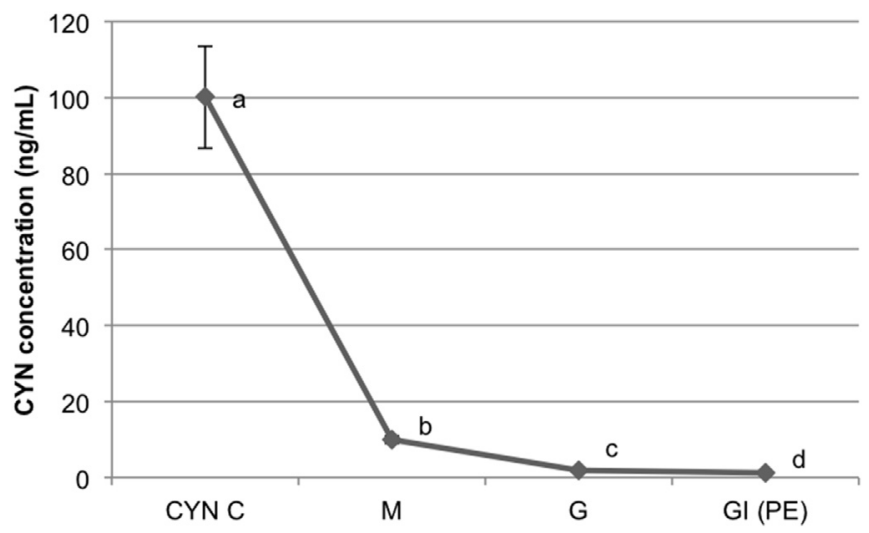

Fig. 5. The concentration of CYN (ng/mL) before (CYN C) and after digestion of its free form in solution (purified CYN). Letters represent each digestive step: mouth (M), gastric $(\mathrm{G})$ and gastrointestinal $(\mathrm{GI})$ with proteolytic enzymes (PE). Values are expressed as the mean $\pm S D(n=3)$. Different letters $(a, b, c$ and $d)$ indicate significant differences $(p<0.05)$. Columns that share the same letter are not significantly different.

To our knowledge, this is the first report presenting the potential effects of human digestion on CYN contained in a food item. According to our findings, it seems to be reasonable to assume that at the tested concentrations, CYN itself would not represent risk to human health. The assumption that the oral bioavailability of CYN is similar to the levels quantified in raw and cooked mussels is erroneous, thus the comparison of TDI with CYN extracted from raw food items is not recommended. In this way, the bioaccessibility of CYN must be integrated in the health risk assessment. In fact, as referred above Falconer et al. (1999) by comparing the effects of various batches of $C$. raciborskii in mice have found that oral toxicity is at least 25-fold lower than intraperitoneal toxicity. Associated to the potential effects of digestive juices, some other important factors may reduce the bioavailability of CYN, such as: (1) uptake potentially dependent of transporter; (2) hepatic metabolism (Norris et al., 2002); (3) removal by intestinal microflora (Nybom, Salminen, \& Meriluoto, 2008); and (4) urinary and fecal excretion (Norris et al., 2001). Finally, although human digestion seems to substantially reduce the CYN availability, the absence of health risk due to consumption of contaminated mussels should be considered cautiously, once the presence of additional toxins in the $C$. raciborskii extracts has been reported (Falconer et al., 1999). Thus, the study of the effects of other toxins as well as the enzymatic-generated metabolites of CYN should be developed in the future.

\section{Conclusion}

In conclusion, this study fills a gap on the knowledge of the influence of food storage and cooking practices on the levels of the CYN in edible organisms. Our results show that the recovery of CYN can be enhanced with frozen storage and its concentration in raw mussels seems not to represent the total amount of toxin available. Although there were no significant differences in CYN concentration in raw, cooked and depurated mussel matrices (flesh), the heat processing and depuration seem to be suitable procedures to reduce this toxin in this edible organism through the removal/ renewal of the intervalval fluid. More importantly, in the industry, these practices can be easily applied and should be considered in the implementation of HACCP system.

This study also provides the first insights of the effects of human digestion on CYN. At the concentrations tested, the digestive juices seem to be effective in the reduction of CYN content, either if it is present in solution or in raw and steamed mussel matrices. According to these findings, CYN itself would not represent risk to human health, which highlights the importance in integrating the bioaccessibility of CYN as a part of risk assessment, since the toxin effectively available for absorption seems to be much lower than the toxin quantified in raw and cooked mussels. Further studies should be developed to identify the contributing factors of CYN removal, particularly the role of digestive juices.

\section{References}

Banker, R., Carmeli, S., Hadas, O., Teltsch, B., Porat, R., \& Sukenik, A. (1997). Identification of cylindrospermopsin in Aphanizomenon ovalisporum (cyanophyceae) isolated from Lake Kinneret, Israel. Journal of Phycology, 33, 613-616.

Banker, R., Teltsch, B., Sukenik, A., \& Carmeli, S. (2000). 7-Epicylindrospermopsin, a toxic minor metabolite of the cyanobacterium Aphanizomenon ovalisporum from Lake Kinneret, Israel. Journal of Natural Products, 63, 387-389.

Chiswell, R. K., Shaw, G. R., Eaglesham, G., Smith, M. J., Norris, R. L., Seawright, A. A. et al. (1999). Stability of cylindrospermopsin, the toxin from the cyanobacterium Cylindrospermopsis raciborskii: effect of $\mathrm{pH}$, temperature, and sunlight on decomposition. Environmental Toxicology, 14, 155-161.

Domingo, J. L (2011). Influence of cooking processes on the concentrations of toxic metals and various organic environmental pollutants in food: a review of the published literature. Critical Reviews in Food Science and Nutrition, 51, 29-37.

Falconer, I. R., Hardy, S. J., Humpage, A. R., Froscio, S. M., Tozer, G. J., \& Hawkins, P. R. (1999). Hepatic and renal toxicity of the blue-green alga (cyanobacterium) Cylindrospermopsis raciborskii in male Swiss albino mice. Environmental Toxicology, 14, 143-150.

Falconer, I. R. \& Humpage, A. R. (2001). Preliminary evidence for in vivo tumour initiation by oral administration of extracts of the blue-green alga Cylindrospermopsis raciborskii containing the toxin cylindrospermopsin. Environmental Toxicology, 16, 192-195.

Falconer, I. R., \& Humpage, A. R. (2006). Cyanobacterial (blue-green algal) toxins in water supplies: cylindrospermopsins. Environmental Toxicology, 21, 299-304.

Freitas, M., Azevedo, J., Carvalho, A. P., Campos, A., \& Vasconcelos, V. (2014). Effects of storage, processing and proteolytic digestion on microcystin-LR concentration in edible clams. Food and Chemical Toxicology, 66, 217-223.

Froscio, S. M., Humpage, A. R., Burcham, P. C., \& Falconer, I. R. (2001). Cell-free protein synthesis inhibition assay for the cyanobacterial toxin cylindrospermopsin. Environmental Toxicology, 16, 408-412.

Froscio, S. M., Humpage, A. R., Burcham, P. C., \& Falconer, I. R. (2003). Cylindrospermopsin-induced protein synthesis inhibition and its dissociation from acute toxicity in mouse hepatocytes. Environmental Toxicology, 18, 243-251.

Froscio, S. M., Humpage, A. R., Wickramasinghe, W., Shaw, G., \& Falconer, I. R. (2008). Interaction of the cyanobacterial toxin cylindrospermopsin with the eukaryotic protein synthesis system. Toxicon, 51, 191-198. 
Griffiths, D. J., \& Saker, M. L. (2003). The Palm Island mystery disease twenty years on: a review of research on the cyanotoxin cylindrospermopsin. Environmental Toxicology, 18, 78-93.

Guerra, A., Etienne-Mesmin, L., Livrelli, V., Denis, S., Blanquet-Diot, S., \& Alric, M. (2012). Relevance and challenges in modeling human gastric and small intestinal digestion. Trends in Biotechnology, 30, 591-600.

Gutiérrez-Praena, D., Jos, Á., Pichardo, S., Moreno, I. M., \& Cameán, A. M. (2013). Presence and bioaccumulation of microcystins and cylindrospermopsin in food and the effectiveness of some cooking techniques at decreasing their concentrations: a review. Food and Chemical Toxicology, 53, 139-152.

Guzmán-Guillén, R., Prieto, A. I., Moreno, I., Soria, M. E., \& Cameán, A. M. (2011). Effects of thermal treatments during cooking, microwave oven and boiling, on the unconjugated microcystin concentration in muscle of fish (Oreochromis niloticus). Food and Chemical Toxicology, 49, 2060-2067.

Humpage, A. R., \& Falconer, I. R. (2003). Oral toxicity of the cyanobacterial toxin cylindrospermopsin in male swiss albino mice: determination of no observed adverse effect level for deriving a drinking water guideline value. Environmental Toxicology, 18, 94-103.

Humpage, A. R., Fontaine, F., Froscio, S., Burcham, P., \& Falconer, I. R. (2005). Cylindrospermopsin genotoxicity and cytotoxicity: role of cytochrome P-450 and oxidative stress. Journal of Toxicology and Environmental Health, Part A, 68, 739-753.

Hur, S. J., Decker, E. A., \& McClements, D. J. (2009). Influence of initial emulsifier type on microstructural changes occurring in emulsified lipids during in vitro digestion. Food Chemistry, 114, 253-262.

Ibelings, B. W., \& Chorus, I. (2007). Accumulation of cyanobacterial toxins in freshwater "seafood" and its consequences for public health: a review. Environmental Pollution, 150, 177-192.

Kinnear, S. (2010). Cylindrospermopsin: a decade of progress on bioaccumulation research. Marine Drugs, 8, 542-564.

Kotai, J. (1972). Instruction for preparation of modified nutrient solution Z8 for algae. Report No. B-11/69 (pp. 1-5). Oslo, Norway: Norwegian Institute for Water Research.

Li, R., Carmichael, W. W., Brittain, S., Eaglesham, G. K., Shaw, G. R., Liu, Y., et al. (2001). First report of the cyanotoxins cylindrospermopsin and deoxycylindrospermopsin from Raphidiopsis curvata (cyanobacteria.). Journal of Phycology, 3, 1121-1126.

Maulvault, A. L., Machado, R., Afonso, C., Lourenço, H. M., Nunes, M. L., Coelho, I. et al. (2011). Bioaccessibility of Hg, Cd and As in cooked black scabbard fish and edible crab. Food and Chemical Toxicology, 49, 2808-2815.

Merkel, S., Dib, B., Maul, R., Köppen, R., Koch, M., \& Nehls, I. (2012). Degradation and epimerization of ergot alkaloids after baking and in vitro digestion. Analytical and Bioanalytical Chemistry, 404, 2489-2497.

Morais, J., Augusto, M., Carvalho, A. P., Vale, M., \& Vasconcelos, V. M. (2008). Cyanobacteria hepatotoxins, microcystins: bioavailability in contaminated mussels exposed to different environmental conditions. European Food Research and Technology, 227, 949-952.

Norris, R. L. G., Eaglesham, G. K., Pierens, G., Shaw, G. R., Smith, M. J., Chiswell, R. K. et al. (1999). Deoxycylindrospermopsin, an analog of cylindrospermopsin from Cylindrospermopsis raciborskii. Environmental Toxicology, 14, 163-165.

Norris, R. L., Seawright, A. A., Shaw, G. R., Senogles, P., Eaglesham, G. K., Smith, M. J., et al. (2002). Hepatic xenobiotic metabolism of cylindrospermopsin in vivo in the mouse. Toxicon, 40, 471-476.

Norris, R. L., Seawright, A. A., Shaw, G. R., Smith, M. J., Chiswell, R. K., \& Moore, M. R. (2001). Distribution of ${ }^{14} \mathrm{C}$-cylindrospermopsin in vivo in the mouse. Environmental Toxicology, 16, 498-505.

Nybom, S. M. K., Salminen, S. J., \& Meriluoto, J. A. O. (2008). Specific strains of probiotic bacteria are efficient in removal of several different cyanobacterial toxins from solution. Toxicon, 52, 214-220.
Ohtani, I., Moore, R. E., \& Runnegar, M. T. C. (1992). Cylindrospermopsin: a potent hepatotoxin from the blue-green alga Cylindrospermopsis raciborskii. Journal of the American Chemical Society, 114, 7941-7942.

O'Neil, J. M., Davis, T. W., Burford, M. A., \& Gobler, C. J. (2012). The rise of harmfu cyanobacteria blooms: the potential roles of eutrophication and climate change. Harmful Algae, 14, 313-334.

Poniedziałek, B., Rzymski, P., \& Kokociński, M. (2012). Cylindrospermopsin: waterlinked potential threat to human health in Europe. Environmental Toxicology and Pharmacology, 34, 651-660.

Preussel, K., Stüken, A., Wiedner, C., Chorus, I., \& Fastner, J. (2006). First report on cylindrospermopsin producing Aphanizomenon flos-aquae (Cyanobacteria) isoated from two German lakes. Toxicon, 47, 156-162.

Rücker, J., Stüken, A., Nixdorf, B., Fastner, J., Chorus, I., \& Wiedner, C. (2007). Concentrations of particulate and dissolved cylindrospermopsin in 21 Aphanizomenon-dominated temperate lakes. Toxicon, 50, 800-809.

Runnegar, M. T., Kong, S. M., Zhong, Y. Z., \& Lu, S. C. (1995). Inhibition of reduced glutathione synthesis by cyanobacterial alkaloid cylindrospermopsin in cultured rat hepatocytes. Biochemical Pharmacology, 49, 219-225.

Runnegar, M. T., Xie, C., Snider, B. B., Wallace, G. A., Weinreb, S. M., \& Kuhlenkamp, J. (2002). In vitro hepatotoxicity of the cyanobacterial alkaloid cylindrospermopsin and related synthetic analogues. Toxicological Sciences, 67, 81-87.

Saker, M. L., Metcalf, J. S., Codd, G. A., \& Vasconcelos, V. M. (2004). Accumulation and depuration of the cyanobacterial toxin cylindrospermopsin in the freshwater mussel Anodonta cygnea. Toxicon, 43, 185-194.

Seifert, M., Mcgregor, G., Eaglesham, G., Wickramasinghe, W., \& Shaw, G. (2007). First evidence for the production of cylindrospermopsin and deoxy-cylindrospermopsin by the freshwater benthic cyanobacterium, Lyngbya wollei (Farlow ex Gomont) Speziale and Dyck. Harmful Algae, 6 , 73-80.

Spoof, L., Berg, K. A., Rapala, J., Lahti, K., Lepisto, L., Metcalf, J. S., et al. (2006). First observation of cylindrospermopsin in Anabaena lapponica isolated from the boreal environment (Finland). Environmental Toxicology, 21 $552-560$.

Terao, K., Ohmori, S., Igarashi, K., Ohtani, I., Watanabe, M. F., Harada, K. I., et al. (1994). Electron microscopic studies on experimental poisoning in mice induced by cylindrospermopsin isolated from blue-green alga Umezakia natans. Toxicon, 32, 833-843.

Tintu, I., Dileep, K. V., Augustine, A., \& Sadasivan, C. (2012). An isoquinolinealkaloid, berberine, can inhibit fungal alpha amylase: enzyme kinetic and molecular modeling studies. Chemical Biology \& Drug Design, 80, 554-560.

Vareli, K., Zarali, E., Zacharioudakis, G. S. A., Vagenas, G., Varelis, V., Pilidis, G., et al (2012). Microcystin producing cyanobacterial communities in Amvrakikos Gulf (Mediterranean Sea, NW Greece) and toxin accumulation in mussels (Mytilus galloprovincialis). Harmful Algae, 15, 109-118.

Versantvoort, C. H. M., Oomen, A. G., Van de Kamp, E., Rompelberg, C. J. M., \& Sips, A. J. A. M. (2005). Applicability of an in vitro digestion model in assessing the bioaccessibility of mycotoxins from food. Food and Chemical Toxicology, 43, $31-40$.

Wörmer, L., Huerta-Fontela, M., Cirés, S., Carrasco, D., \& Quesada, A. (2010). Natura photodegradation of the cyanobacterial toxins microcystin and cylindrospermopsin. Environmental Science \& Technology, 44, 3002-3007.

Zhang, D., Xie, P., \& Chen, J. (2010). Effects of temperature on the stability of microcystins in muscle of fish and its consequences for food safety. Bulletin of Environmental Contamination and Toxicology, 84, 202-207.

Zsila, F., Kámán, J., Bogányi, B., \& Józsvai, D. (2011). Binding of alkaloids into the S1 specificity pocket of $\alpha$-chymotrypsin: evidence from induced circular dichroism spectra. Organic \& Biomolecular Chemistry, 9, 4127-4137. 